\title{
Workshops med patient videocases
}

- giver medicinstuderende ny og autentisk erfaring med beskrivelse og tolkning af sygdomsbilleder

\section{Thomas Balslev}

\section{MHPE, PhD}

Børneafdelingen, Regionshospitalet Viborg, Hospitalsenhed Midt og Center for Medicinsk Uddannelse, Aarhus N

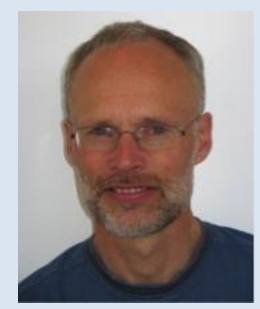

\section{Anne Leegaard}

$M D$

Børneafdelingen, Regionshospitalet Herning, Hospitalsenhed Vest

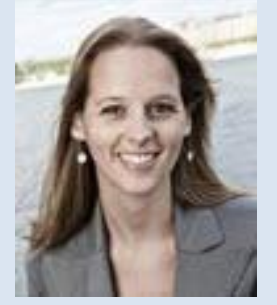




\section{Thomas Balslev}

Forskningsansvarlig overlæge, speciallæge i

børnesygdomme, Master in Health Professions Education, Ph.d.

\section{Thomas.balslev@midt.rm.dk}

Thomas Balslev har arbejdet på børneafdelinger i Toronto, Canada og på Aarhus Universitetshospital. Nu er han ansat som overlæge ved børneafdelingen, Regionshospitalet Viborg, hvor han er forskningsansvarlig og arbejder med børneneurologi. Thomas Balslevs forskning fokuserer på autentisk, kollaborativ uddannelse af medicinstuderende og læger.

\section{Anne Leegaard}

Anne Leegaard har arbejdet på børneafdelingen, Regionshospitalet, Viborg og senest som introduktionsreservelæge på børneafdelingen, Regionshospitalet Herning. Hun stiler mod en speciallægeuddannelse i pædiatri. 


\section{Dansk abstract}

Når medicinstuderende begynder at møde patienter, starter de en langvarig proces med dannelse af kognitive mønstre kaldet illness scripts. Hvert enkelt nyt møde med en patient bidrager med nye detaljer. Imidlertid mindsker ændringer i arbejdstilrettelæggelse eller naturlige årstidsvariationer de studerendes chance for at møde virkelige patienter. Workshops med autentiske patient videocases kan fremme nødvendig script dannelse.

Vi identificerede en række vigtige tilstande, som de medicinstuderende ofte ikke når at møde under deres 16 dage i klinikophold på en børneafdeling. Vi fremstillede 8 digitale patient videocases med passende hyppighed, relevans og teknisk kvalitet. De studerende beskrev og fortolkede dem før de blev gennemgået med en underviser. Efterfølgende udfyldte de studerende et spørgeskema.

I alt deltog 65 medicinstuderende. Andelen, som udelukkende har mødt patienter med de 8 tilstande via patient videocases var 36,8-87,5\%, afhængigt af tilstanden. Et lavt procenttal tyder på at tilstanden er relativt almindelig, og at der er en betydelig chance for at en medicinstuderende møder den hos en virkelig patient, mens et højt procenttal tyder på at tilstanden er relativt sjælden, og at chancen for at en medicinstuderende møder den hos en virkelig patient dermed er lille.

\section{English abstract}

Medical students are at the onset of a long-lasting process with creation of cognitive patterns named illness scripts. Every meeting with a patient adds new details to scripts. Changes of organization at work, however, or natural fluctuations in frequencies of diseases diminish chances to meet patients. Workshops with patient video cases can counteract these barriers by enhancing desirable script formation and learning.

We identified a number of conditions that the medical students often do not meet in real life during the 16-day paediatric clerkship. We prepared 8 digital patient video cases with appropriate frequency, relevance and technical quality. The medical students described and analysed them prior to participating in two interactive workshops with a facilitator. Following the workshops, they filled in a questionnaire.

A total of 65 medical students participated. A total of 36.8-87.5\% of medical students met the 8 types of patients only through the shown patient video cases. Low percentages indicated more common disorders and a reasonable likelihood for a medical student meeting a real patient, 
while high percentages indicated less common disorders with a low chance for a medical student having an encounter. 


\section{Introduktion}

Uddannelse af medicinstuderende og læger er i vidt omfang arbejdsbaseret (Swanwick, 2005). For de studerende i form af klinikophold, og for lægerne i form af ansættelser ved hospitaler eller i almen praksis. Der er hyppigst tale om uformel læring, dvs. læring som finder sted spontant og uplanlagt for eksempel i forbindelse med møder med patienter (Eraut, 2000). Der kan også være tale om formel læring, som er planlagt og organiseret med en underviser.

I denne artikel vil vi fokusere på den læring der kan opstå, når de medicinstuderende, dvs. novicerne, begynder at udvikle diagnostisk ekspertise under deres klinikophold. For mange medicinstuderende vil det være den første gang de lærer, mens de arbejder. Læringen initieres når de møder deres første patienter, hvor der udvikles sammenhænge mellem årsager til og konsekvenser af sygdom (Boshuizen, 2000). Efterhånden som den kliniske erfaring udbygges, dannes kognitive mønstre kaldet illness scripts. Hvert enkelt illness script indeholder muliggørende faktorer, prognose og muligheder for behandling. Der er mange studier som viser at antallet af de muliggørende faktorer i illness scripts stiger med ekspertisen. Hvert enkelt nyt møde mellem en patient og den medicinstuderende eller lægen, bidrager med nye detaljer. Det er karakteristisk for speciallægen, dvs. eksperten, at han eller hun hele tiden monitorerer om dette eller hint illness script nu også passer med den aktuelle situation eller patient. Hvis ikke der er match, kan eksperten i følge denne teori lynhurtigt - og uden særlig anstrengelse - aktivere et nyt illness script.

Gentagne møder med patienter og deres diagnostiske udfordringer er derfor ekstremt vigtige for udvikling af ekspertise. Imidlertid kan korte klinikophold, ændringer i arbejdstilrettelæggelsen på sygehusene eller naturlige årstidsvariationer i sygdomshyppighed betyde at de medicinstuderende slet ikke møder visse typer virkelige patienter. Samtidigt ved vi at de studerende i stigende omfang, dagligt eller ugentligt anvender digitale medier, som bliver understøttet af Aarhus Universitet (Stenalt \& Godsk, 2008). Underviserne er begyndt at anvende digitale medier eller fora, og der er interesse blandt både de studerende og underviserne for at anvende web baseret video i undervisningen.

Studenterinddragende aktiviteter, især understøttelse af samarbejde, er vigtig (Godsk \& Dalsgaard 2008). Kontrollerede undersøgelser af reservelæger under speciallægeuddannelse har påvist betydelig og værdifuld vidensdeling når en gruppe af reservelæger analyserer og drøfter patient videocases (PVCs) i stedet for tekst cases (Balslev et al, 2009). Vi ved også at lægers diagnostiske præcision kan øges ved brug af PVCs, især når den kliniske ræsonnering først trænes verbalt i små grupper, efterfulgt af lytning til en ekspert som tænker højt (Balslev et al, 2010). PVCs ser derfor ud til at være en værdifuld hjælp til at skabe 
virtuelle, interaktive og autentiske læringsmiljøer som kan fremme nødvendig illness script dannelse og dermed de diagnostiske færdigheder.

I denne artikel beskrives processen fra den teoretiske samt empiriske baggrund til udvikling og implementering af et obligatorisk, bæredygtigt undervisningstilbud bestående af workshops med patient videocases (WPVCs) til de medicinstuderende på kandidatuddannelsen, 5. semester, familie samfund, Aarhus Universitet. For det første ville vi belyse, om det er muligt på basis af pædiatrisk faglitteratur og viden om effekten af PVCs at udvælge et overskueligt antal digitale PVCs til workshops til de medicinstuderende. For det andet ville vi belyse hvor hyppigt de medicinstuderende lykkes med at opleve og analysere patienter i form af digitale PVCs, hvor de ellers ikke har mødt patienttyperne. For det tredje ville vi belyse, hvor mange studerende, som kan huske om de før har set en PVC som illustrerer netop disse patienttyper.

\section{Metoder}

Vi tog udgangspunkt i læringsmål nr. 2 for 5. semester

(Studieordning.au.dk): Studenterne skal kunne beskrive de væsentligste sygdomme mht. disposition, genese, symptomatologi og prognose. Vi ønskede at identificere 6-10 PVC's, som på bedst mulig måde kunne bidrage med læring om udvalgte, væsentlige sygdomme i forbindelse med to interaktive workshops under klinikopholdet på 16 dage på en børneafdeling.

Et panel af speciallæger og yngre læger udvalgte ved hjælp af en trinvis proces en række væsentlige og egnede kliniske tilstande. (Se figur 1) For det første skulle hver tilstand indebære et relevant, dynamisk, visuelt element. Videocases er nemlig fremragende til at formidle bevægelser, men vi ved også at bevægelserne skal være relevante og ikke overflødige (Roy \& McMahon, 2012). Hvis ikke tilstandene er karakteriseret af relevante bevægelser, må vi derfor regne med at fotos, og ikke video, er mest egnet. 


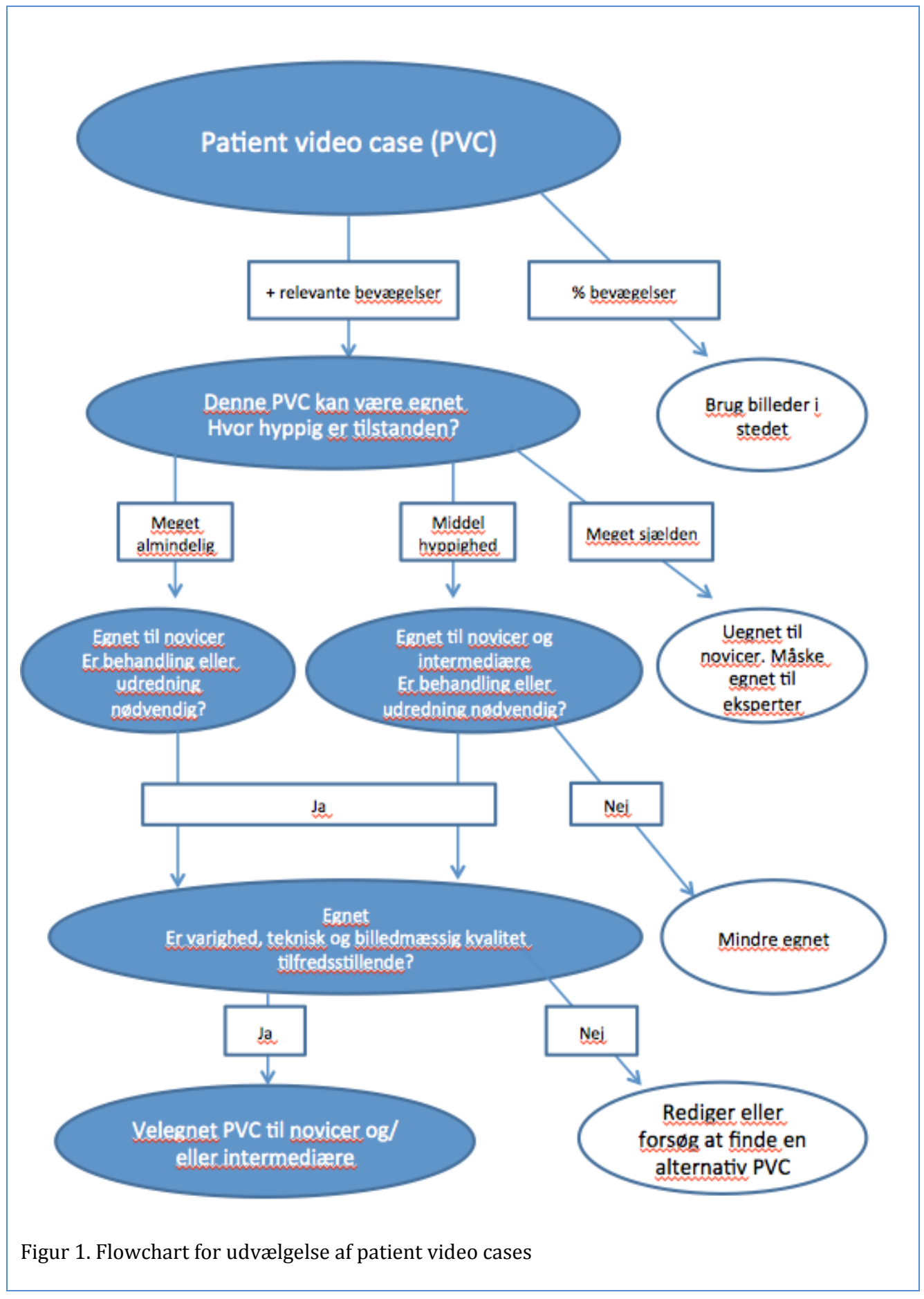

De to næste kriterier angik væsentligheden af tilstanden. Det første af disse var hyppigheden. De hyppige tilstande blev foretrukket til de medicinstuderende. Derpå så vi på om udredning eller behandling var nødvendig. Vi foretrak tilstande, hvor udredning var væsentlig for at udelukke eller bekræfte alvorlig sygdom, og tilstande, som var behandlingskrævende. De to sidste kriterier var varigheden og den tekniske, billedmæssige kvalitet. Optagelserne måtte ikke have for lang 
varighed, og de relevante objektive tegn skulle være tydelige. Hver PVC startede med en kort tekst som angav barnets alder, køn og primære symptom. Vi endte op med 8 PVCs med middel varighed på 62 sekunder (Tabel 1). På fire PVC's spillede lydsiden en væsentlig rolle for den kliniske ræsonnering og diagnosen. Et stillbillede fra hver enkelt PVC med tilhørende diagnose eller illness-script ses i Figur 2.

Tabel 1 Karakteristika for de 8 valgte patient video cases

\begin{tabular}{|c|c|c|c|c|c|c|}
\hline & patient diagnose (illness script) & $\begin{array}{l}\text { patie } \\
\text { nt } \\
\text { alder }\end{array}$ & hyppighed & $\begin{array}{l}\text { betyden } \\
\text { de lyd }\end{array}$ & $\begin{array}{l}\text { antal } \\
\text { sekve } \\
\text { nser }\end{array}$ & $\begin{array}{l}\text { Varigh } \\
\text { ed i } \\
\text { sekun } \\
\text { der }\end{array}$ \\
\hline 1 & Infantile spasmer & $\begin{array}{l}5 \\
\text { mdr. }\end{array}$ & sjælden & ja & 2 & 52 \\
\hline 2 & Meningococsygdom med petechier & $2 \mathrm{år}$ & sjælden & ja & 2 & 62 \\
\hline 3 & Muskelsvind & $3 \mathrm{år}$ & sjælden & nej & 4 & 41 \\
\hline 4 & $\begin{array}{l}\text { Pylorus stenose med } \\
\text { ventrikelperistaltik }\end{array}$ & $\begin{array}{ll}5 \\
\text { uger }\end{array}$ & sjælden & nej & 1 & 138 \\
\hline 5 & $\begin{array}{l}\text { Cerebral parese med forsinket } \\
\text { motorisk udvikling og knyttet hånd }\end{array}$ & $\begin{array}{l}7 \\
\text { mdr. }\end{array}$ & almindelig & nej & 1 & 89 \\
\hline 6 & $\begin{array}{l}\text { Pneumokok lungebetændelse med } \\
\text { indtrækninger }\end{array}$ & 2 år & almindelig & ja & 3 & 39 \\
\hline 7 & $\begin{array}{l}\text { RS-virus lungebetændelse med } \\
\text { indtrækninger }\end{array}$ & $\begin{array}{l}2 \\
\text { uger }\end{array}$ & $\begin{array}{l}\text { meget } \\
\text { almindelig } \\
+ \\
\text { sæsonvari } \\
\text { ation }\end{array}$ & ja & 2 & 63 \\
\hline 8 & Generel udviklingshæmning & $\begin{array}{l}7 \\
\text { mdr. }\end{array}$ & $\begin{array}{l}\text { meget } \\
\text { almindelig }\end{array}$ & nej & 2 & 105 \\
\hline
\end{tabular}

Optagelserne blev foretaget af 1 . forfatteren i forbindelse med undersøgelse eller behandling på hospitalet. Forældrene gav forhåndstilladelse til optagelse, og så selv optagelserne igennem før de gav tilladelse til at de kunne bruges til undervisning af sundhedsprofessionelle. Råoptagelserne blev opbevaret i aflåst lokale på hospitalet. For hver enkelt PVC fremstillede to erfarne børnelæger en kort tekst, som beskrev, hvad en erfaren børnelæge ville tænke på mens han eller hun forsøgte at stille en diagnose på denne PVC. Denne tekst var tilgængelig for facilitator, men ikke for de medicinstuderende. Samtlige PVCs var tilgængelige for facilitatorer via en webservice, og for de medicinstuderende i afdelingernes konferencerum.

Vi planlagde to workshops med PVCs. De studerende modtog på forhånd information om at de skulle deltage i workshops med autentiske PVCs. De vidste, at formålet var at træne opmærksomhed over for kliniske fund, og at træne den kliniske ræsonnering hen imod den (eller de) mest 
sandsynlige diagnose(r). Den første workshop fandt sted i begyndelsen af deres klinikophold på børneafdelingen og varede op til 30 minutter. Vi valgte 3 tilstande med så høj hyppighed, at det var sandsynligt at de medicinstuderende ville møde en eller flere af disse tilstande under klinikopholdet. Dermed ville de medicinstuderende erhverve sig viden og diagnostiske færdigheder, som de ville kunne bruge under klinikopholdet. De medicinstuderende startede med at arbejde sammen, uden at facilitator var til stede, med disse tre cases. Derpå afholdt en speciallæge eller en kommende speciallæge en W-PVC med analyse af de væsentlige fund samt den kliniske ræsonnering.

De medicinstuderende fik til opgave sammen at analysere de resterede 5 PVCs som forberedelse til den anden W-PVC, som blev gennemført en af de sidste dage i klinikopholdet. Disse 5 PVCs vurderede vi var så ualmindelige, at det var mest sandsynligt at de medicinstuderende ikke ville møde patienttyperne i virkeligheden. Facilitatorerne blev instrueret ved møder, hvor læringsmålene blev gennemgået samt en række ønskværdige former for mesterlære adfærd blev demonstreret (Collins 2006). Der blev især lagt vægt på metoderne demonstration, coaching, stilladsering og artikulering. Den anden workshop varede op til 60 minutter.

Deltagerne var studerende på 5. semester af kandidatdelen ved medicinstudiet på Aarhus Universitet under deres kliniske ophold på en børneafdeling i Region Midtjylland. Deltagelse i W-PVCs var obligatorisk og deltagelsesprocenten var over 90. Data blev indsamlet i perioden oktober 2013 til juni 2014. Mere end $60 \%$ af de medicinstuderende fik tilbud om at deltage med udfyldelse af spørgeskema. Der blev ikke udleveret spørgeskemaer under enkelte klinikophold, da det ikke var alle facilitatorer, som havde adgang til spørgeskemaerne. Alle som fik tilbud om at deltage med udfyldelse af spørgeskema, deltog. I alt 10 ud af 65 spørgeskemaer $(15,4 \%)$ havde inkomplette data.

\section{Målinger}

Efterfølgende udfyldte de medicinstuderende et spørgeskema om varighed af deres forberedelse til W-PVCs. De angav for hver enkelt af de 8 PVCs om de havde mødt tilstandene i virkeligheden, og om de havde mødt tilstandene som PVCs før de så dem som led i W-PVCs under klinikopholdet.

\section{Resultater}

Karakteristika for de 8 PVCs ses i tabel 1. Varigheden var 41-138 sekunder. De medicinstuderende brugte i gennemsnit 1,2 (spændvidde: 0-4) timer på forberedelse til de to workshops. Der deltog i alt 65 studenter i workshops på 4 børneafdelinger. Manglende svar udgjorde under $10 \%$ af alle svar. 


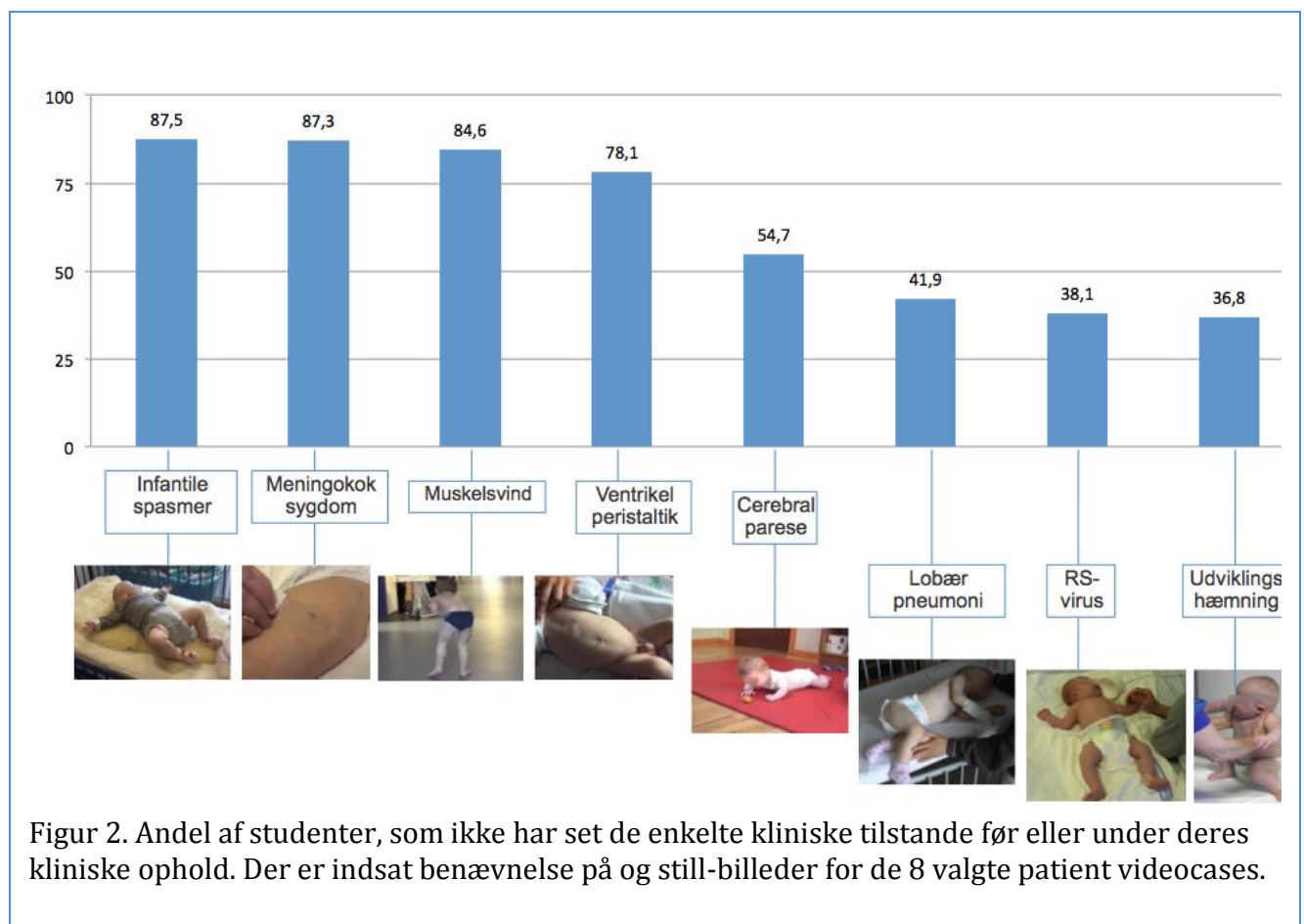

Næsten alle medicinstuderende deltog i begge workshops. Mellem 36,8 og 87,5 \% så udelukkende disse tilstande i form af de aktuelle PVCs (Figur 3), hvilket dels afspejler variationer i tilstandenes prævalens og incidens, dels hvor tilgængelige de 8 tilstande er på børneafdelingerne, eller hvor opsøgende de medicinstuderende er. Det er således bekræftet at en meget betydelig andel af de medicinstuderende ikke selv har set en klinisk præsentation af disse tilstande.

Mellem 7,9 og 49,2 \% af de studerende havde allerede set en anden patient video case med disse tilstande før de deltog i vores workshops. De tre PVCs med infektionssygdomme blev rapporteret med lavest frekvens af de medicinstuderende: RSV (7,9\%), pneumoni (11,3\%) og meningokoksygdom (14,3\%). De højeste frekvenser blev rapporteret for infantile spasmer $(49,2 \%)$, muskelsvind $(40,6 \%)$ og ventrikelperistaltik $(37,5 \%)$.

\section{Diskussion}

Vi fik bekræftet at det var muligt at udvikle en overskuelig liste med relevante PVCs til W-PVCs til de medicinstuderende. Vi fik også bekræftet at en stor andel af medicinstuderende (36,8-87,5 \%) ikke møder disse tilstande hos virkelige patienter i løbet af deres kliniske ophold. Det validerer at de valgte PVCs virkeligt var relevante. Takket være de 8 PVCs har alle disse medicinstuderende nu set disse tilstande i form af autentiske PVCs, analyseret dem med andre medicinstuderende, og deltaget i en workshop, faciliteret af en kliniker. Dette miljø simulerer den 
arbejdsopgave der hyppigt opstår, når et klinisk team af medicinstuderende og læger under deres arbejde møder en patient, som skal udredes og behandles.

Procentdelene kan afspejle forskelle i incidens og prævalens - for eksempel varer en serie med infantile spasmer kun få sekunder eller minutter, mens muskelsvind er en kronisk tilstand. Procentdelene kan også afspejle lav tilgængelighed af visse tilstande, som sjældent leder til indlæggelse eller ambulant opfølgning, eller at nogle af de medicinstuderende ikke er opmærksomme på eller opsøger de rigtige patienter, når muligheden opstår.

Vores undersøgelse viser at W-PVCs kan give særdeles gode muligheder for at træne opmærksomhed over for kliniske fund, og at træne den kliniske ræsonnering hen imod den (eller de) mest sandsynlige diagnose(r). Dermed kan de medicinstuderende tage nogle tidlige og vigtige skridt henimod udvikling af deres egne illness scripts.

Vi mener at rækkefølgen, hvor de medicinstuderende først verbaliserer deres fund og diagnoser og derpå drøfter dem med og lytter til en mere erfaren kliniker eller facilitator, er en væsentlig styrke. Dermed kan deltagerne på forhånd dele deres læring, og med afsæt i workshoppen kan de lære endnu mere. Styrken ved den digitale, diagnostiske færdighedstræning ligger især i autenticiteten og i interaktiviteten. For det første gør PVCs både udseendet, bevægelserne og eventuelle ledsagende, karakteristiske lyde tilgængelige for beskrivelse og drøftelse. For det andet giver forberedelserne til workshops og endeligt selve workshops rige lejligheder for vidensdeling - shared cognition (Balslev et al, 2009).

Nogle af de medicinstuderende (7,9-49,2 \%) havde allerede set en PVC med sygdomsbillederne. Man kunne så spørge, om undervisningen dermed ville være overflødig for dem som allerede havde mødt problemstillingerne. Vi mener ikke det er et problem at se og analysere nye PVCs for specifikke problemstillinger, for ingen kliniske cases er helt identiske. Det afspejler ofte virkeligheden, hvor nye cases er variationer på tidligere cases. Eventuelle forskelle kan endda, hvis de altså ses, opfattes og fortolkes, bidrage til yderligere udvikling af ekspertise. Der ligger nye perspektiver i at sammenligne kontrasterende eller lignende PVCs, som kan bidrage værdifuldt til workshop undervisning, især senere i uddannelsen mod speciallæge anerkendelse.

Det er en svaghed ved denne undersøgelse, at deltagelsesprocenten var omkring 60. Manglende deltagelse skyldtes dog manglende udlevering af spørgeskemaer, og ikke et fravalg fra de studerendes side. Derfor er der ikke grund til at tro at de medicinstuderende, som ikke deltog, havde andre erfaringer end dem som deltog. 
W-PVCs, som demonstrerer relevante bevægelser og er væsentlige i form af hyppighed og udrednings- eller behandlingskrav, er derfor et værdifuldt supplement til de medicinstuderendes møder med virkelige patienter. Formatet kan med fordel integreres med den øvrige arbejdsbaserede læring under de medicinstuderendes klinikophold.

W-PVCs kan ligne virtuelle patienter, som er computerbaserede simulationer af møder med patienter, hvor der indgår sygehistorier med billed- og/eller video-materiale (Cook, 2007 og Berman, 2011). Der er dog også væsentlige forskelle. I et virtuel patient program er patienten ikke nødvendigvis autentisk. Programmet udvikler sig med input fra den studerende og tilhørende respons fra computerprogrammet. Der er ikke en underviser til stede. Ved W-PVCs er patienterne autentiske, man er ikke afhængig af respons fra et computerprogram, og der er aktiv deltagelse af en tilstedeværende underviser.

For at et virtuel patient program skal fungere er det nødvendigt med samarbejde mellem uddannelsesinstitutionerne om indholdet, en konsistent pædagogisk indgangsvinkel, integration med klinikopholdene samt infrastruktur for vedligeholdelse (Berman, 2011). På grund af lighederne med et virtuel patient program anbefaler vi tilsvarende forudsætninger for udvikling af W-PVCs. I tillæg anbefaler vi at der er en underviser/facilitator til stede ved W-PVCs, dels fordi det er under klinikopholdene at klinikerne er mest tilgængelige; men især for at monitorere og facilitere de studerendes samarbejde og læring med respekt for de individuelle læringsbehov. En klar ulempe ved virtuelle patienter er nemlig omkostningerne ved at udvikle gode programmer, som kan bruges af forskellige studerende. Der vil være en betydelig risiko for at et virtuelt læringsmiljø ikke adapterer sig til de studerendes viden og færdigheder. Det kan i værste fald give den studerende unødig usikkerhed og modvirke læring (Cook, 2007).

Læring med PVCs er ikke begrænset til studerende, som arbejder i grupper. Autentiske PVCs anvendes hyppigt i lærebøger og videnskabelige tidskrifter, gerne tilgængelige via scanningstags, så man kan se dem på skærmen på sin mobiltelefon. Dermed kan man øve såvel visuel opmærksomhed og klinisk ræsonnering med mulighed for at styrke detaljegraden i egne illness scripts.

Ny forskning vil kunne klarlægge, hvordan man vælger de mest relevante og egnede PVCs til andre målgrupper. Læger i speciallægeuddannelse i pædiatri og almen medicin kan have bedst læring ved deltagelse i W-PVCs med helt andre PVCs end de her undersøgte. 


\section{Taksigelser}

Tak til de forældre, som lod deres børn filme og gav tilladelse til at optagelserne kunne anvendes til forbedring af medicinstuderende og lægers uddannelse. Thomas Thelle takkes for at lave ekspertbeskrivelser af de enkelte PVCs. Tak til de speciallæger og de kommende speciallæger som faciliterede workshops med de medicinstuderende. Tak til de medicinstuderende, som tog sig tid til at udfylde spørgeskemaer.

\section{Referencer}

Balslev T, de Grave W, Muijtjens AMM, Eika B, Scherpbier AJJA. (2009). The development of shared cognition in paediatric residents analysing a patient video versus a paper patient case. Advances in the Health Professions Education 14(4):557-565.

Balslev T, de Grave W, Muijtjens A, Scherpbier A. (2010). Enhancing diagnostic accuracy among non-experts by use of video-cases. Pediatrics 125(3):e570-6.

Berman NB, Fall LH, Chessman AW et al. (2011). A collaborative model for developing and maintaining virtual patients for medical education. Medical Teacher 33:319-324.

Bjork RA, Dunlosky J, Kornell N. (2013). Self-regulated learning: Beliefs, techniques and illusions. Annu Rev Psychol 64:417-44.

Boshuizen HPA, Schmidt HG. (2000). The development of clinical reasoning expertise: implications for teaching. In: Higgs J, Jones M, eds. Clinical Reasoning in the Health Professions. 2nd edn. Oxford: ButterworthHeinemann; pp 15-22.

Collins A. (2006). Cognitive apprenticeship. I: Sawyer RK. The Cambridge Handbook of the Learning Sciences. Cambridge University Press p 4760 .

Cook DA. (2007) Web-based learning: pros, cons and controversies. Clinical Medicine 7(1):37-42.

Eraut M. (2000). Non-formal learning and tacit knowledge in professional work. British Journal of Educational Psychology 70(1) 113-136.

Godsk M, Dalsgaard C. (2009). Implementering af lyd, video og interaktive medier i undervisningen. Læring og Medier (LOM) - nr. 2:1-4.

Roy RB, McMahon GT. (2012). Video-based cases disrupt deep critical thinking in problem-based learning. Medical Education 46:426-435.

Stenalt MH, Godsk M. (2008). Studerende og underviseres brug af digitale medier. - En kvantitativ undersøgelse af Aarhus Universitets studerende og underviseres brug af digitale medier og internettet anno 2008.

Læring og Medier (LOM) 2, 1-15.

Studieordning.au.dk 
Swanwick T. (2005). Informal learning in postgraduate medical education: from cognitivism to 'culturism'. Medical Education 39:859-865. 